Published every January - June and July - December

JURNAL ASET (AKUNTANSI RISET)

ISSN : 2541-0342 (Online). ISSN : 2086-2563 (Print). http://ejournal.upi.edu/index.php/aset

\title{
Analisis Struktur Modal, Tingkat Pertumbuhan dan Ukuran Perusahaan Terhadap Nilai Tambah Ekonomi
}

\author{
Aryanti Ratnawati ${ }^{1}$, Iman Sinarjadi ${ }^{2}$
}

Jurusan Akuntansi, Fakultas Ekonomi, Universitas Sangga Buana YPKP, Bandung, Indonesia.

\begin{abstract}
Investors need to know the ability of the company and the prospect of the company in the future, then investors hope to have a tool that can be a reference to investing. The purpose of this study is to know the description of Capital Structure, Corporate Growth Rate and Size of Firm on Economic Value Added / EVA either partially or simultaneously. The object of this study is Index 30. This index consists of 30 leading shares whose constituents are part of the LQ45 Index. The research method used is survey method and type of method used is descriptive method verification. The analysis used to test the hypothesis is multiple regression analysis and data in the form of corporate financial statements for the period 2009-2013. With the level of significance ( $\alpha$ ) of 0.05 obtained the results of the first hypothesis testing showed that partially Capital Structure, growth rate, and firm size significantly influence Economic Value Added. While the results of testing The second hypothesis shows that the capital structure, company growth rate, and company size simultaneously significantly influence Economic Value Added.
\end{abstract}

Keywords. capital structure; growth rate; a size of firm; economic value added; index 30

Abstrak. Investor perlu mengetahui kemampuan perusahaan dan prospek perusahaan di masa yang akan datang, maka investor berharap memiliki alat yang dapat menjadi acuan dalam berinvestasi . Tujuan penelitian ini adalah untuk mengetahui deskripsi mengenai Struktur Modal, Tingkat Pertumbuhan Perusahaan Dan Ukuran Perusahaan terhadap Nilai Tambah Ekonomi/ EVA(Nitami) baik secara parsial maupun simultan. Objek penelitian ini adalah Indeks 30. Indeks ini terdiri dari 30 saham unggulan yang konstituennya merupakan bagian dari Indeks LQ45. Metode penelitian yang digunakan adalah metode survey dan jenis metode yang digunakan adalah metode deskriptif verifikatif. Analisi yang digunakan untuk menguji hipotesis adalah analisis regresi berganda, dan data berupa laporan keuangan perusahaan periode 2009-2013. Dengan tingkat signifikansi $(\alpha)$ sebesar 0,05 diperoleh hasil pengujian hipotesis pertama menunjukkan bahwa secara parsial Struktur Modal, tingkat pertumbuhan dan ukuran perusahaan berpengaruh secara signifikan terhadap Nilai Tambah Ekonomi. Sedangkan Hasil pengujian Hipotesis kedua menunjukkan bahwa struktur modal, tingkat pertumbuhan perusahaan dan ukuran perusahaan secara bersama-sama/ simultan berpengaruh secara signifikan terhadap Nilai Tambah Ekonomi.

Kata Kunci. struktur modal; tingkat pertumbuhan perusahaan; ukuran perusahaan nilai tambah ekonomi (nitami); indeks 30

Corresponding author. J1. PHH Mustofa (Suci) No 68. Kota Bandung. Provinsi Jawa Barat. Email :

aryanti.ratnawati@yahoo.com. Email : hrimansinarjadi@yahoo.co.id

How to cite this article. Ratnawati, Sinarjadi (2015). Analisis Struktur Modal, Tingkat Pertumbuhan Dan Ukuran Perusahaan Terhadap Nilai Tambah Ekonomi. Jurnal Aset (Akuntansi Riset). Program Studi Akuntansi Fakultas Pendidikan Indonesia Universitas Pendidikan Indonesia, 7 (1), 13-28. Retrieved from http://ejournal.upi.edu/index.php/aset

History of article. Received: Januari 2015, Revision: Maret 2015, Published: Juni 2015 


\section{PENDAHULUAN}

Keuntungan merupakan indikator kemampuan perusahaan dalam memenuhi kewajiban kepada para penyandang dana dan juga merupakan elemen dalam penciptaan nilai perusahaan yang menunjukkan prospek perusahaan di masa yang akan datang, karena nilai perusahaan merupakan ukuran keberhasilan dalam pelaksanaan fungsi-fungsi keuangan.

Investor yang menanamkan dana di pasar modal harus mampu memanfaatkan semua informasi untuk menganalisa pasar dan investasinya dengan harapan memperoleh keuntungan yang maksimal. Analisis Nitami merupakan suatu cara dalam pengukuran kinerja perusahaan, seberapa besar perusahaan yang go public berhasil memenuhi keinginan para investor atau penyandang dana bagi perusahaan.

Pasar modal (capital market) merupakan pasar untuk berbagai instrumen keuangan jangka panjang yang bisa diperjualbelikan, baik surat utang (obligasi), ekuiti (saham), reksa dana, instrumen derivatif maupun instrumen lainnya. Pasar modal memfasilitasi berbagai sarana dan prasarana kegiatan jual beli dan kegiatan terkait lainnya.

Agar para investor mengetahui kemampuan perusahaan dan prospek perusahaan di masa yang akan datang PT Bursa Efek Indonesia (BEI) pada tanggal 23 April 2012 meluncurkan Indeks baru bernama IDX 30. Indeks ini terdiri dari 30 saham unggulan yang konstituennya merupakan bagian dari Indeks LQ45. Adapun faktorfaktor yang menjadi kriteria dasar keanggotaan IDX 30 adalah aktivitas transaksi seperti nilai transaksi, frekuensi transaksi, jumlah hari transaksi, serta kapitalisasi pasar. Selain menggunakan kriteria kuantitatif, dalam pemilihan komponen IDX 30 Bursa Efek Indonesia juga memperhatikan aspek-aspek kualitatif seperti kondisi keuangan, prospek pertumbuhan, serta faktor-faktor lain terkait kelangsungan usaha perusahaan. Metode penghitungan IDX 30 adalah sama dengan metode penghitungan indeks-indeks lain yang ada di BEI sekarang, yaitu pembobotan berdasarkan market capitalization weighted average.

Berdasarkan hal tersebut maka investor perlu melihat Nilai Tambah Ekonominya. Konsep Nilai Tambah Ekonomi (Nitami) merupakan pendekatan baru dalam menilai kinerja perusahaan secara adil maksudnya konsep Nitami memperhatikan sepenuhnya para penyandang dana dalam hai kepentingan, harapan dan derajat keadilan, yang diukur dengan mempergunakan ukuran tertimbang (weighted) dan struktur modal awal yang ada (Agus Sartono,2001:103).

Dengan penghitungan Nitami diharapkan dapat memperoleh hasil perhitungan pada upaya penciptaan nilai perusahaan (Creating a Firms value) yang lebih realistis.

Trend rata-rata Nilai Tambah Ekonomi (Nitami) perusahaan yang listing di PT. BEI tahun 2007-2011 fluktuatif dengan trend meningkat dengan gambar sebagai berikut:

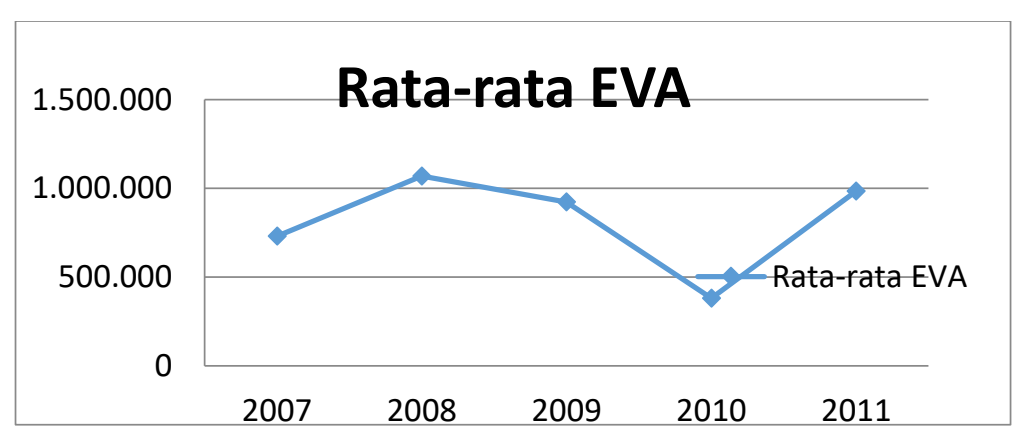

Sumber : Data Keuangan 27 Perusahaan Komponen Indeks 30 yang diolah

Gambar 1. Grafik Rata-Rata Nilai Tambah Ekonomi 
Melihat trend Nitami periode 2007 2011 menunjukkan bahwa keberhasilan bisnis dalam memaksimalkan nilai perusahaan tergantung pada efektivitas gabungan tujuan antara tujuan para pemegang saham dan manajer melalui rancangan skema insentif yang tepat, struktur modal yang optimal adalah struktur modal yang dapat meminimalkan biaya modal rata-rata atau memaksimalkan nilai perusahaan atau struktur modal yang optimal adalah suatu struktur modal yang biaya marjinal riil hutang (marginal real cost of debt) sama dengan biaya marjinal riil modal sendiri (marginal real cost of equity). Namun, dalam kenyataan sulit bagi perusahaan untuk menentukan suatu struktur modal yang terbaik dalam suatu komposisi pembelanjaan yang tepat. Lebih mudah apabila perusahaan mencoba menaksir dalam suatu range berapa tingkat leverage yang tepat bagi perusahaan .

Struktur modal yang ideal adalah yang memberikan biaya modal minimum, selain itu juga struktur modal (capital structure) adalah perbandingan atau imbangan pendanaan jangka panjang perusahaan yang ditunjukkan oleh perbandingan hutang jangka panjang terhadap modal sendiri.

Nilai Tobin' $q$ dihasilkan dari penjumlahan nilai pasar saham (market value of all outstanding stock) dan nilai pasar hutang (market value of all debt) dibandingkan dengan nilai seluruh modal yang ditempatkan dalam aktiva produksi (replacement value of all production capacity), tingkat pertumbuhan perusahaan juga merupakan faktor yang mempengaruhi struktur modal, perusahaan yang memiliki tingkat pertumbuhan pesat cenderung lebih banyak menggunakan hutang daripada perusahaan yang memiliki tingkat pertumbuhan yang lebih lambat (Weston dan Copeland, 2010:174).

Berdasarkan teori pertumbuhan perusahaan berbanding lurus dengan ukuran perusahaan, sehingga semakin cepat pertumbuhan perusahaan maka semakin besar pula ukuran perusahaan, sehingga ukuran perusahaan berpengaruh terhadap struktur modal karena perusahaan yang lebih besar akan mudah memperoleh pinjaman dibandingkan perusahaan kecil. Ukuran perusahaan menggambarkan besar kecilnya suatu perusahaan yang ditunjukkan oleh total aktiva, total penjualan, rata-rata tingkat penjualan, dan rata-rata total aktiva (Feri dan Jones,1999) dan (Masidonda, Maski, dan Idrus, 1999).

Ukuran perusahaan juga menjadi faktor yang perlu diperhatikan dalam menentukan struktur modal. Perusahaan besar dapat mengakses pasar modal dan dengan kemudahan tersebut perusahaan memiliki fleksibilitas dan kemampuan untuk mendapatkan dana atau permodalan. Perusahaan-perusahaan besar cenderung lebih mudah untuk memperoleh pinjaman dari pihak ketiga, karena kemampuannya mengakses pihak lain atau jaminan yang dimiliki berupa asset bernilai lebih besar dibanding perusahaan kecil. Namun secara kenyataan lebih banyak pengusaha besar sukses atau perusahaan besar di dunia ini yang menggunakan hutang sebagai cara yang efektif untuk dapat mengembangkan usaha secara cepat.

Berdasarkan latar belakang yang telah diuraikan diatas, maka rumusan masalah dapat diidentifikasikan sebagai berikut : Bagaimana Struktur Modal, Tingkat Pertumbuhan Perusahaan dan Ukuran berpengaruh terhadap Nilai Tambah Ekonomi (Nitami) pada perusahaan-perusahaan yang termasuk Komponen Indeks 30 periode tahun 2009 sampai dengan tahun 2013, baik secara parsial maupun secara simultan.

Dengan analisis tersebut maka tujuan untuk dapat mengetahui, menganalisis dan mengkaji tingkat Struktur Modal, Tingkat Pertumbuhan Perusahaan dan Ukuran berpengaruh terhadap Nilai Tambah Ekonomi (Nitami) pada perusahaan-perusahaan yang termasuk Komponen Indeks 30 periode tahun 2009 sampai dengan tahun 2013 dapat dicapai.

Manfaat dalam analisis ini dapat berupa sumbangan dalam pengembangan Ilmu Manajemen, terutama pada bidang Manajemen Keuangan khususnya mengenai Struktur Modal, Tingkat Pertumbuhan Perusahaan, Ukuran Perusahaan dan Economic Value Added atau Nilai Tambah Ekonomi (Nitami), dengan sasaran hasil analisis ini dapat memberikan sumbangan pemikiran tentang 
apa yang harus diperbaiki dan apa yang harus ditingkatkan dalam penerapan penilaian kinerja keuangan, dapat menambah pengetahuan dan wawasan tentang penilaian kinerja keuangan perusahaan, terutama mengenai Struktur Modal, Tingkat Pertumbuhan Perusahaan, Ukuran Perusahaan dan Economic Value Added atau Nilai Tambah Ekonomi (Nitami) pada perusahaan.

\section{KAJIAN LITERATUR}

Pasar modal (capital market) merupakan pasar untuk berbagai instrumen keuangan jangka panjang yang bisa diperjualbelikan, baik surat utang (obligasi), ekuiti (saham), reksa dana, instrumen derivatif maupun instrumen lainnya. Pasar modal memfasilitasi berbagai sarana dan prasarana kegiatan jual beli dan kegiatan terkait lainnya. Menurut Tendelilin $(2007,13)$, Pasar modal dapat diartikan sebagai pasar untuk memeperjual belikan sekuritas yang umumnya memeiliki umur lebih dari satu tahun, seperti saham dan obligasi, sedangkan tempat transaksi jual beli sekuritas disebut bursa efek.Meningkatkan nilai perusahaan sampai pada tingkat struktur modal yang optimal adalh dengan penggunaan modal sendiri dan modal asing dalam memenuhi kebutuhan modal perusahaan menjadi sangat penting dalam manajemen keuangan perusahaan. Hal ini dikarenakan pentingnya perimbangan antara modal asing dengan modal sendiri (disebut sebagai struktur modal).

Menurut Sutrisno (2001:9) dan Monica (2006:1). Sejauh ini, penelitian mengenai struktur modal, bertujuan untuk menentukan model atau teori struktur modal yang dapat menjelaskan perilaku keputusan pendanaan perusahaan. Beberapa faktor yang umumnya dipertimbangkan dalam mengambil keputusan mengenai struktur modal pada perusahaan.

Dihubungkan dengan adanya aturan struktur finansial konservatif yang menyatakan bahwa besarnya modal sendiri hendaknya dapat menutup jumlah aktiva tetap dan aktiva lain yang bersifat permanen.

Selain itu menurut Agus Sartono (2001, 225). Struktur modal (capital structure) adalah $\mathbf{1}$. perbandingan atau imbangan pendanaan 2 . jangka panjang perusahaan yang ditunjukkan oleh perbandingan hutang jangka panjang terhadap modal sendiri.

Kebutuhan dana perusahaan dari modal sendiri berasal dari modal saham, laba ditahan. Pendanaan yang berasal dari luar, yaitu dari hutang (debt financing). Struktur modal yang optimal dapat meminimalkan biaya penggunaan modal keseluruhan atau biaya modal rata-rata (ko), sehingga memaksimal kan nilai perusahaan.

\section{Tingkat Pertumbuhan}

Tingkat pertumbuhan perusahaan juga merupakan faktor yang mempengaruhi struktur modal, perusahaan yang memiliki tingkat pertumbuhan pesat cenderung lebih banyak menggunakan hutang daripada perusahaan yang memiliki tingkat pertumbuhan yang lebih lambat (Weston dan Brigham, 1994:174). Growth ratio atau rasio pertumbuhan yang mengukur seberapa baik perusahaan mempertahankan posisi ekonominya, baik dalam industrinya maupun dalam kegiatan ekonomi secara keseluruhan (Weston \& Copeland, 1992).

Menurut Agus Sartono (2001, 248), Pertumbuhan menunjukkan kemampuan perusahaan untuk dapat bertahan dalam kondisi persaingan. Semakin besar kebutuhan pembiayaan di masa mendatang semakin besar keinginan perusahaan menahan laba. Potensi pertumbuhan perusahaan diukur dari besarnya biaya penelitian dan pengembangan.

Sedangkan tingkat pertumbuhan yang awalnya dikemukakan oleh Tobin dan Brainard (Tobin, 1969) serta dan Kallapur dan Trombley( 2001) menyatakan bahwa Nilai Tobin' $q$ dihasilkan dari penjumlahan nilai pasar saham (market value of all outstanding stock) dan nilai pasar hutang (market value of all debt) dibandingkan dengan nilai seluruh modal yang ditempatkan dalam aktiva produksi (replacement value of all production capacity), dimana pertumbuhan adalah :

Tobin $q=$ Total Debt +
$\frac{\text { (Outstanding Share x Closing Price) }}{\text { Book Value of Assts }}$

Ukuran Perusahaan 
Menurut pendapat Panjaitan, 2004. (jurnal-bei.blogspot.com/2011), Ukuran Perusahaan adalah pengelompokkan perusahaan atas dasar skala operasi (besar atau kecil)dapat dipakai oleh investor sebagai salah satu variabel dalam menentukan keputusan investasi. Tolok ukur yang menunjukkan besar kecilnya suatu perusahaan, antara lain total penjualan, rata-rata tingkat penjualan dan total aktiva.

Menurut pendapat Indriani ( 2005) Perusahaan besar umumnya memiliki total aktiva yang besar pula sehingga dapat menarik investor untuk menanamkan modalnya pada perusahaan tersebut dalam jangka waktu yang relatif lama, selain itu juga mencerminkan bahwa perusahaan relatif lebih stabil dan lebih mampu menghasilkan laba dibanding perusahaan dengan total asset yang kecil.

Indriani (2005) juga menyatakan bahwa berpendapat ukuran perusahaan adalah suatu skala dimana dapat diklasifikasikan besar kecil perusahaan menurut berbagai cara, antara lain: total aktiva, log size, nilai pasar saham, dan lain-lain.

Sedangkan Machfoedz berpendapat bahwa pada dasarnya ukuran perusahaan hanya terbagi dalam 3 kategori yaitu perusahaan besar, perusahaan menengah dan perusahaan kecil. Penentuan ukuran perusahaan ini didasarkan kepada total asset . Ukuran perusahaan bisa diukur dengan menggunakan total aktiva, penjualan, atau modal dari perusahaan tersebut. Salah satu tolok ukur yang menunjukkan besar kecilnya perusahaan adalah ukuran aktiva dari perusahaan tersebut. Perusahaan yang memiliki total aktiva besar menunjukkan bahwa perusahaan tersebut telah mencapai tahap kedewasaan dimana dalam tahap ini arus kas perusahaan sudah positif dan dianggap memiliki prospek yang baik. Dikarenakan aktiva merupakan tolok ukur besaran atau skala suatu perusahaan. Biasanya perusahaan besar mempunyai aktiva yang besar pula nilainya.

\section{Economic Value Added atau Nilai Tambah Ekonomi}

Alat ukur yang berkaitan langsung dengan kepentingan analisis kinerja perusahaan menurut Mirza dan Imbuh (1999, 31) yaitu : Nilai Tambah Ekonomi (Nitami) dan Market Value Added ( MVA) Nitami adalah ukuran nilai tambah ekonomis (value creation) yang dihasilkan perusahaan sebagai akibat dari aktivitas atau strategi manajemen. Nitami yang positif menandakan perusahaan berhasil menciptakan nilai bagi pemilik modal karena perusahaan mampu menghasilkan tingkat pengahasilan yang melebihi tingkat biaya modalnya.

Sedangkan pengertian Economic Value Added menurut Widayanto (1993:115) adalah: EVA dilandasi pada konsep bahwa dalam pengukuran laba suatu perusahaan kita harus dengan adil mempertimbangkan harapan setiap penyedia dana. Dengan penghitungan EVA diharapkan dapat memperoleh hasil perhitungan pada upaya penciptaan nilai perusahaan (Creating a Firms value) yang lebih realistis.

Menurut Kiryanto (1997:125) Nilai bisa diartikan "nilai guna, daya guna maupun benefits yang dinikmati oleh Stakeholders". Hal ini disebabkan karena EVA dihitung berdasarkan kepentingan kreditur dan terutama para pemegang saham dan bukan berdasar nilai buku yang bersifat historis. Karena seorang investor yang rasional tentu akan mendasarkan keputusannya pada data keuangan yang paling up to date, bukan pada data yang bersifat historis.

\section{Proses Penghitungan Nilai Tambah Ekonomi (Nitami)}

Suatu sistem pengukuran kinerja dalam perusahaan harus dapat membedakan aktivitas yang value added dengan aktivitas yang non value added. Pembagian ini diperlukan sehingga manajemen organisasi dapat fokus untuk mengurangi biaya - biaya yang timbul akibat aktivitas yang tidak menambah nilai 
Beberapa pengertian Nilai Tambah Ekonomi/ Nitami yang dikemukakan para ahli sebagai berikut:

Anjan V. Thakor (2000, 152)

Economic Value Added (Also Called EVA) = Revenue-Direct Costs (including taxes) - oppurtunity cost of using capital $=$ aftertax profit - oppurtunity cost of using capital.

S. David Young $(2001,24)$

EVA $=$ NOPAT - Capital Charges

EVA is just another term for "Economic Profit" NOPAT = Net Operating Profit After Tax

Capital

Capital Charges $=$ Investasi Capital $x$ Cost of

Erich A. Helfet $(2000,48)$

Economic Value Added (EVA) represents a yardstick for measuring whether a business is earning above cost of capital of the resourches (capital base) it employs.

$$
\text { EVA = NOPAT }- \text { C. } k
$$

(Adjusted)

Where $:$ NOPAT $=$ Net Operating Profit After Taxes

Tabel 1. Kajian-kajian Penelitian Terdahulu

\begin{tabular}{|c|c|c|c|c|}
\hline \multirow[t]{2}{*}{ No. } & \multirow[t]{2}{*}{ Nama Peneliti } & \multirow[t]{2}{*}{ Judul Penelitian } & \multicolumn{2}{|c|}{ Penelitian Relevan } \\
\hline & & & Persamaan & Perbedaan \\
\hline 1. & Monica (2006) & 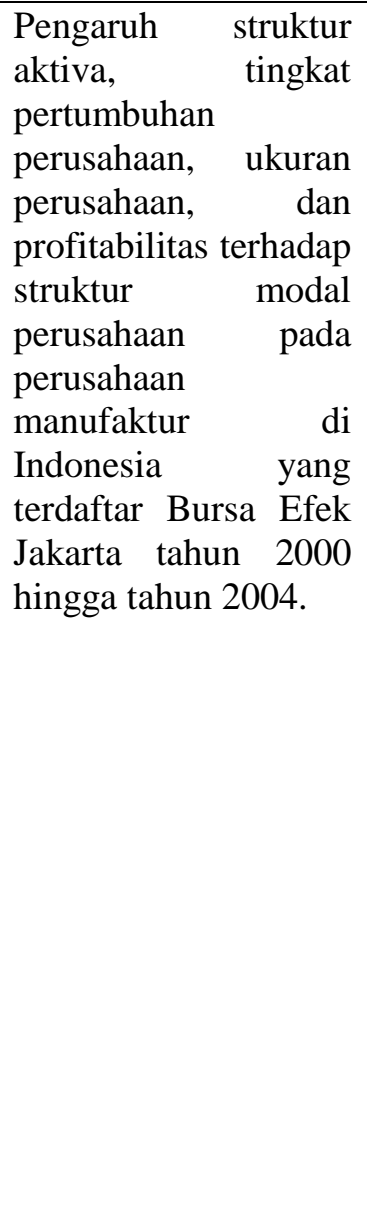 & $\begin{array}{lr}\text { Menggunakan } & \text { Tingkat } \\
\text { Pertumbuhan } & \\
\text { Perusahaan, } & \text { Ukuran } \\
\text { perusahaan } & \text { dan } \\
\text { profitabiliitas } & \text { sebagai } \\
\text { Variabel Bebas dan } \\
\text { Struktur Modal } \\
\text { Variabel Terikat }\end{array}$ & $\begin{array}{l}\text { Pada penelitian ini, variable } \\
\text { yang digunakan adalah } \\
\text { struktur aktiva, tingkat } \\
\text { pertumbuhan perusahaan, } \\
\text { ukuran perusahaan, dan } \\
\text { profitabilitas terhadap } \\
\text { struktur modal perusahaan. } \\
\text { Objek Penelitian pada } \\
\text { perusahaan manufaktur di } \\
\text { Indonesia yang terdaftar } \\
\text { Bursa Efek Jakarta tahun } \\
\text { 2000 hingga tahun 2004. } \\
\text { Sedangkan Pada penelitian } \\
\text { yang saya lakukan variable } \\
\text { yang digunakan adalah } \\
\text { Struktur Modal, Tingkat } \\
\text { Pertumbuhan Perusahaan } \\
\text { Dan Ukuran Perusahaan } \\
\text { terhadap Nilai Tambah } \\
\text { Ekonomi (Nitami) pada } \\
\text { perusahaan- perusahaan } \\
\text { yang termasuk dalam } \\
\text { Komponen IDX30 yang } \\
\text { terdaftar pada PT. Bursa } \\
\text { Efek Indonesia Periode } \\
\text { Tahun 2007 - 2011. } \\
\text { Penelitian dilakukan di } \\
\text { Pojok Bursa USB YPKP. }\end{array}$ \\
\hline
\end{tabular}

\begin{tabular}{lllrlll}
\hline 3. Wiwik & Utami & $\begin{array}{l}\text { Pengaruh } \\
\text { aktiva, } \\
\text { (2006) }\end{array}$ & $\begin{aligned} \text { struktur } \\
\text { tingkat }\end{aligned}$ & $\begin{array}{l}\text { Menggunakan } \\
\text { Aktiva, }\end{array}$ & $\begin{array}{l}\text { Struktur } \\
\text { Tingkat }\end{array}$ & Pada penelitian ini , \\
& & & Pertumbuhan, yang digunakan & Ukuran adalah Struktur Aktiva, \\
\hline
\end{tabular}

18 | Jurnal Aset (Akuntansi Riset) Vol.7 | No.1 | 2015 capital (WACC).

$$
\begin{array}{ll}
C & =\text { Capital base employed } \\
K & =\text { Weighted average cost of }
\end{array}
$$

Apabila perusahaan memiliki NITAMI yang positif, maka dapat dikatakan bahwa manajemen dalam perusahaan tersebut telah menciptakan nilai (creating value). Sebaliknya, apabila nilai NITAMI negatif, dinamakan distructing atau destroying value.

\section{Studi Empiris}

Beberapa penelitian terdahulu mengenai faktor-faktor yang mempengaruhi Nilai Tambah Ekonomi (Nitami) disajikan dalam Tabel berikut ini : 


\begin{tabular}{|c|c|c|c|c|}
\hline \multirow[t]{3}{*}{ No. } & \multirow[t]{2}{*}{ Nama Peneliti } & \multirow[t]{2}{*}{ Judul Penelitian } & \multicolumn{2}{|c|}{ Penelitian Relevan } \\
\hline & & & Persamaan & Perbedaan \\
\hline & & $\begin{array}{l}\text { perusahaan, ukuran } \\
\text { perusahaan, } \\
\text { profitabilitas, dan cost } \\
\text { of equity terhadap } \\
\text { struktur modal } \\
\text { perusahaan Pada } \\
\text { perusahaan otomotif } \\
\text { yang terdaftar di } \\
\text { Bursa Efek Jakarta } \\
\text { selama periode 2004- } \\
\text { 2006;. }\end{array}$ & $\begin{array}{ll}\text { Perusahaan } & \text { dan } \\
\text { profitabilitas dan cost } \\
\text { equity sebagai Variabel } \\
\text { Bebas dan Struktur } \\
\text { Modal sebagai variable } \\
\text { terikat }\end{array}$ & $\begin{array}{lr}\text { Tingkat } & \text { Pertumbuhan } \\
\text { Perusahaan, } & \text { Ukuran } \\
\text { Perusahaan, Profitabilitas, } & \text { of } \\
\text { dan Cost of Equity } \\
\text { terhadap Struktur Modal } \\
\text { Objek } \\
\text { perusahaan Penelitian } \\
\text { otomotif yang terdaftar di } \\
\text { Bursa Efek Jakarta selama } \\
\text { periode 2004-2006. } \\
\text { Penelitian dilakukan di } \\
\text { Bursa Efek Jakarta. } \\
\text { Sedangkan Pada penelitian } \\
\text { yang saya lakukan variable } \\
\text { yang digunakan adalah } \\
\text { Struktur Modal, Tingkat } \\
\text { Pertumbuhan Perusahaan } \\
\text { Dan Ukuran Perusahaan } \\
\text { terhadap Nilai Tambah } \\
\text { Ekonomi (Nitami) pada } \\
\text { perusahaan- perusahaan } \\
\text { yang termasuk dalam } \\
\text { Komponen IDX30 yang } \\
\text { terdaftar pada PT. Bursa } \\
\text { Efek Indonesia Periode } \\
\text { Tahun 2007 - 2011. } \\
\text { Penelitian dilakukan di } \\
\text { Pojok Bursa USB YPKP. }\end{array}$ \\
\hline
\end{tabular}

\begin{tabular}{|c|c|c|c|c|}
\hline 5. & $\begin{array}{l}\text { Kusumaningru } \\
\text { m (2010) }\end{array}$ & $\begin{array}{l}\text { Pengaruh } \\
\text { profitabilitas, } \\
\text { pertumbuhan asset, } \\
\text { dan ukuran } \\
\text { perusahaan terhadap } \\
\text { struktur modal (studi } \\
\text { kasus perusahaan real } \\
\text { estate and property } \\
\text { yang terdaftar di BEI } \\
\text { Tahun 2005-2009 }\end{array}$ & $\begin{array}{l}\text { Menggunakan } \\
\text { Profitabilita, } \\
\text { pertumbuhan asset, } \\
\text { ukuran perusahaan, } \\
\text { sebagai variable besa dan } \\
\text { struktur modal sebagai } \\
\text { variable terikat. }\end{array}$ & $\begin{array}{c}\text { Pada penelitian ini, } \\
\text { variable yang digunakan } \\
\text { adalah Profitabilitas, } \\
\text { Pertumbuhan Asset, dan } \\
\text { Ukuran Perusahaan } \\
\text { terhadap Struktur Modal } \\
\text { (studi kasus perusahaan } \\
\text { Objek Penelitian adalah } \\
\text { perusahaan real estate and } \\
\text { property yang terdaftar di } \\
\text { BEI Tahun 2005-2009. } \\
\text { Penelitian di lakukan di } \\
\text { Bursa Efek Indonesia. } \\
\text { Sedangkan pada penelitian } \\
\text { yang saya lakukan variable } \\
\text { yang digunakan adalah } \\
\text { Struktur Modal, Tingkat } \\
\text { Pertumbuhan Perusahaan } \\
\text { Dan Ukuran Perusahaan } \\
\text { terhadap Nilai Tambah } \\
\text { Ekonomi (Nitami) pada } \\
\text { perusahaan- perusahaan } \\
\text { yang termasuk dalam } \\
\text { Komponen IDX30 yang }\end{array}$ \\
\hline
\end{tabular}




\begin{tabular}{ccc}
\hline No. Nama Peneliti & Judul Penelitian & Penelitian Relevan \\
\cline { 2 - 3 } & & Perbedaan \\
\hline & terdaftar pada PT. Bursa \\
& Efek Indonesia Periode \\
& Tahun 2007 - 2011. \\
& Penelitian dilakukan di \\
& Pojok Bursa USB YPKP. \\
\hline
\end{tabular}

Dari uraian tersebut di atas, maka paradigma pemikiran dalam penelitian ini dapat digambarkan pada Gambar 2 seperti berikut :

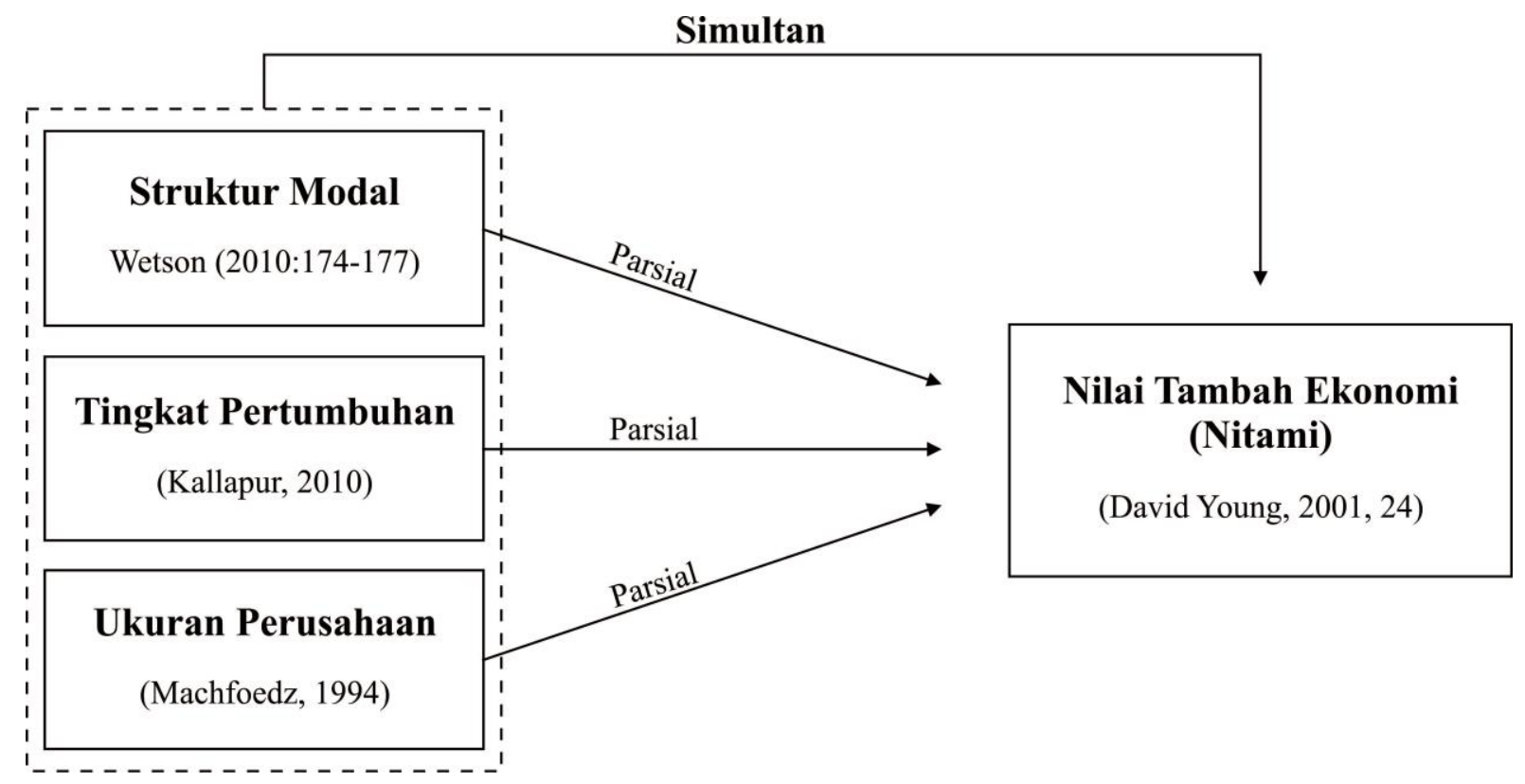

Gambar 2 Paradigma Penelitian

\section{Hipotesis Penelitian}

Berdasarkan kerangka pemikiran sebagaimana dikemukakan di atas, maka dapat dirumusan hipotesis penelitian yang merupakan dugaan sementara mengenai hubungan dan pengaruh antara variable yang akan diuji kebenarannya. Rumusan

$\mathrm{H}_{1,2}$ : Struktur Modal, Tingkat Pertumbuhan Perusahaan dan Ukuran Perusahaan secara simultan dan parsial berpengaruh terhadap EVA/ Nilai Tambah Ekonomi (Nitami).

\section{METODOLOGI PENELITIAN}

Data penelitian yang tertera dalam tulisan ini dikumpulkan dengan data sekunder yang diperoleh dari laporan tahunan pada perusahaan IDX 30 yang listing di PT. Bursa Efek Indonesia.

Fokus penelitian ini adalah yang berhubungan dengan struktur modal, tingkat pertumbuhan perusahaan, ukuran perusahaan, , dan nilai tambah ekonomi ( Nitami), karena obyek yang diteliti memungkinkan dilakukan proses sampling data, maka metode penelitian yang digunakan adalah metode survey dan jenis metode yang digunakan adalah metode deskriptif verifikatif, Menurut Nazir (2003:55)

Metode deskriptif adalah metode penelitian untuk membuat gambaran mengenai situasi atau kejadian, sehingga metode ini berkehendak mengadakan akumulasi data 
dasar belaka, sedangkan menurut Mashuri metode verifikatif adalah memeriksa benar tidaknya apabila dijelaskan untuk menguji suatu cara dengan atau tanpa perbaikan yang telah dilaksanakan di tempat lain dengan mengatasi masalah yang serupa dengan kehidupan (Nazir,2008:45). Sifat data yang digunakan dalam penelitian ini adalah data time series.
Penelitian dilakukan pada perusahaanperusahaan yang masuk dalam komponen Indeks 30 dalam kurun waktu tahun 2009 sampai dengan 2013, yaitu sebanyak 30 Perusahaan dan yang memenuhi syarat sebanyak 27 perusahaan, yaitu :

Daftar Perusahaan Komponen Indeks 30 Bursa Efek Indonesia (BEI) Periode Februari Juli 2012 :

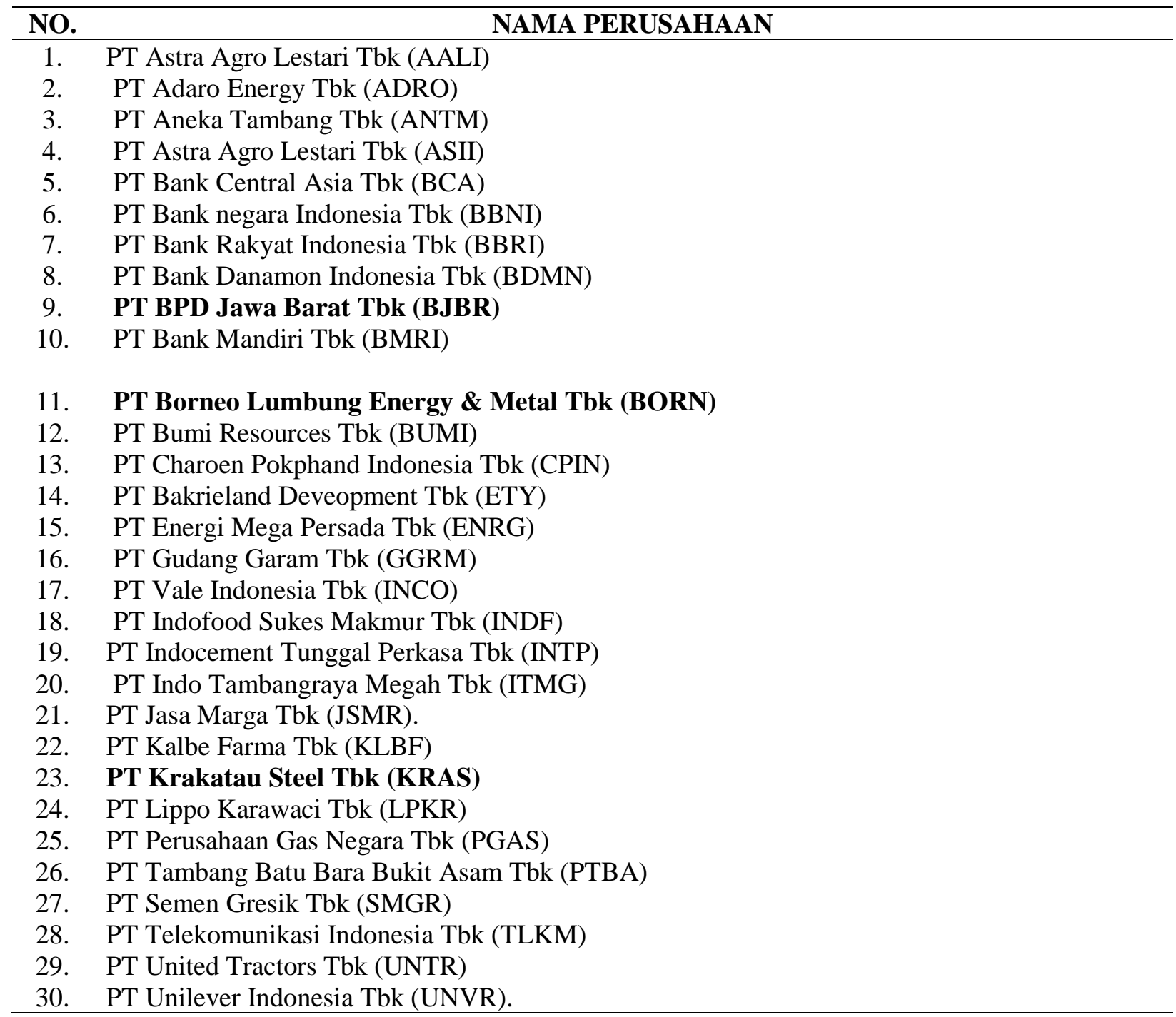

Sumber : Data BEI periode Februari - Juli 2013

Sebelum melakukan penelitian, digunakan metode sampling jenuh. Metode sampling jenuh adalah teknik penentuan sampel bila semua anggota populasi digunakan sebagai sampel. Hal ini sering dilakukan bila jumlah populasi relatif kecil, kurang dari 30 perusahaan yang ingin membuat generalisasi dengan kesalahan yang sangat kecil. Istilah lain sampel jenuh adalah sensus, dimana 
semua anggota populasi dijadikan sampel 1. Mengumpulkan data laporan keuangan (Sugiono, 2005:96).

Penelitian ini menggunakan jenis data sekunder, yaitu data yang telah diolah dan disajikan atau disampaikan melalui berbagai media, seperti buku, jurnal, internet serta sumber lain yang bergaitan erat dengan objek penelitian.

Data yang digunakan dalam penelitian ini adalah datasekunder yang diperoleh dari dari laporan keuangan internal perusahaan tahunan dari tahun 2009 sampai dengan 2012 yang didalamnya memuat data Hutang Jangka Panjang, hutang Jangka Pendek, Net Operating Income, Total asset, Book Value, Jumlah Saham beredar serta harga pembukaan dan penutupan saham.

Metoda pengumpulan data dalam penelitian ini dilakukan dengan cara melakukanstudi pustaka, yaitu : tahunan 27 perusahaan komponen Iindeks30 periode tahun 2009 - 2013, melalui Pojok Bursa Universitas Sangga Buana YPKP .

Pengujian asumsi klasik dilakukan untuk memberikan kepastian bahwa persamaan regresi yang didapatkan memiliki ketepatan dalam estimasi, tidak bias dan konsisten. Uji asumsi klasik yang digunakan abtara lain: uji multikolinearitas, uji autokorelasi, uji heteroskedastisitas, uji normalitas.

\section{HASIL DAN PEMBAHASAN}

Analisis ini digunakan untuk memprediksi besarnya pengaruh struktur modal, pertumbuhan, dan ukuran perusahaan terhadap NITAMI. Adapun perolehan nilai tambah ekonomi perusahaan kelompok Indeks 30 periode 2009 - 2013 adalah sebagai berikut

Melakukan kajian referensi yang berupa jurnal, buku, artikel dan laporan penelitian terdahulu.

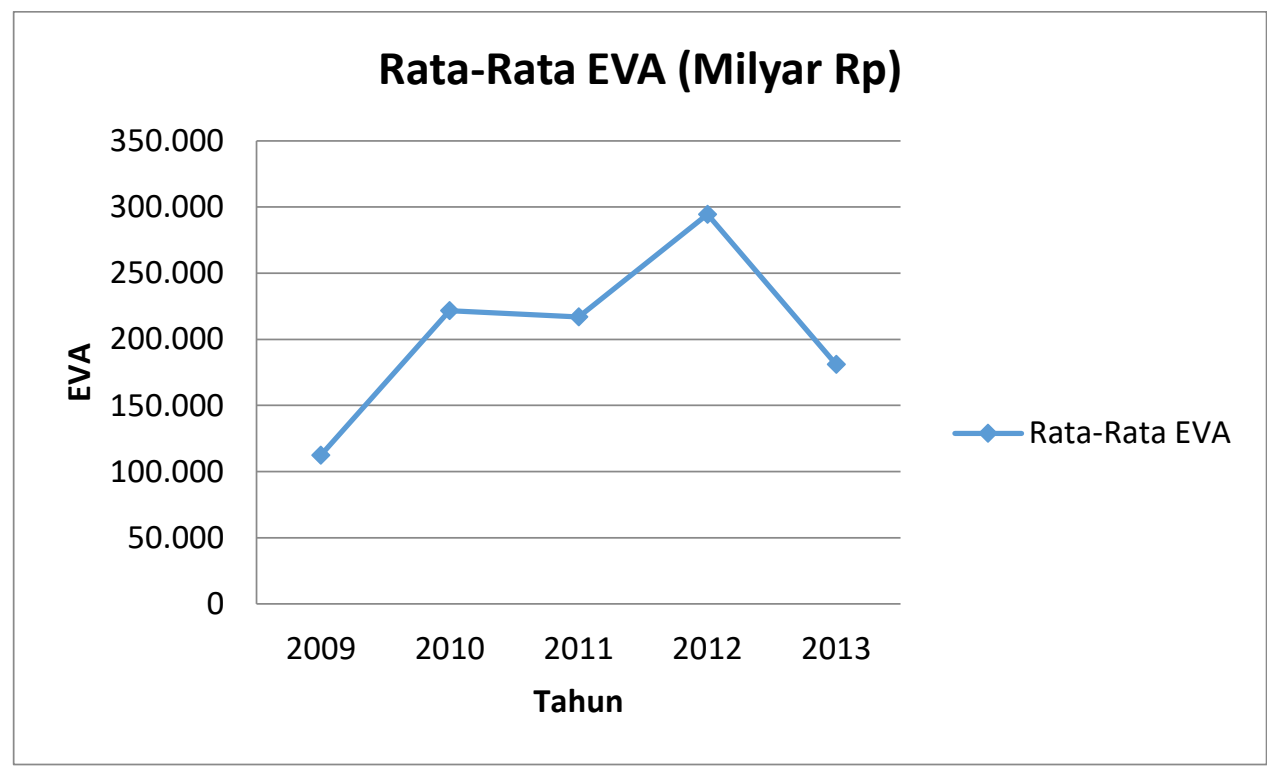

Gambar 3. Perolehan Nitami 2009-2013

Sumber : Data Keuangan Perusahaan Indeks 30 yang diolah 2014 
Berdasarkan pembatasan masalah dan hipotesis yang telah dikemukakan sebelumnya maka diperoleh hasil pengolahan data dengan program statistik SPSS 20.0 yang tampak pada Tabel berikut ini.

Tabel 3. Hasil Perhitungan Regresi Linear Berganda

\begin{tabular}{|c|c|c|c|c|c|c|c|c|c|c|}
\hline & & & Coeffic & cients ${ }^{a}$ & & & & & & \\
\hline \multirow{2}{*}{ Model } & \multicolumn{2}{|c|}{$\begin{array}{c}\text { Unstandardized } \\
\text { Coefficients }\end{array}$} & \multirow{2}{*}{$\begin{array}{c}\begin{array}{c}\text { Standardized } \\
\text { Coefficients }\end{array} \\
\text { Beta }\end{array}$} & \multirow{2}{*}{$\mathrm{T}$} & \multirow{2}{*}{ Sig. } & \multicolumn{3}{|c|}{ Correlations } & \multicolumn{2}{|c|}{$\begin{array}{c}\text { Collinearity } \\
\text { Statistics }\end{array}$} \\
\hline & B & Std. Error & & & & $\begin{array}{l}\text { Zero- } \\
\text { order }\end{array}$ & Partial & Part & Tolerance & VIF \\
\hline (Constant) & 2.168 & 1.061 & & 2.043 & .043 & & & & & \\
\hline $\begin{array}{l}\text { Struktur } \\
\text { Modal }\end{array}$ & -.010 & .002 & -.271 & $\mid-5.001$ & .000 & -.454 & -.400 & $\mid-.261$ & .928 & 1.078 \\
\hline Pertumbuhan & 3.228 & .465 & .381 & 6.946 & .000 & .568 & .519 & .362 & .902 & 1.109 \\
\hline Ukuran & .534 & .063 & .472 & 8.497 & .000 & .646 & .596 & .443 & .881 & 1.135 \\
\hline
\end{tabular}

a. Dependent Variable: NITAMI

Berdasarkan tabel di atas diperoleh model persamaan regresi linier berganda sebagai berikut :

$Y=2.168-0.010 X_{1}+3.228 X_{2}+0.534 X_{3}+\epsilon$ Dimana :

Y : Nitami

$\mathrm{X}_{1} \quad$ : Struktur Modal

$\mathrm{X}_{2} \quad$ : Pertumbuhan

$\mathrm{X}_{3}$ : Ukuran Perusahaan
C : Distubance error (Faktor pengganggu/residual)

Berdasarkan output SPSS 19.0 nampak bahwa pengaruh secara bersama-sama 3 (tiga) variabel independen (struktur modal, pertumbuhan dan ukuran perusahaan) terhadap Nitami seperti ditunjukkan pada Tabel berikut ini

Tabel 4. Hasil Perhitungan Hubungan Keeratan

\begin{tabular}{|c|c|c|c|c|c|c|c|c|c|c|}
\hline \multicolumn{11}{|c|}{ Model Summary ${ }^{b}$} \\
\hline \multirow[b]{2}{*}{ Model } & \multirow[b]{2}{*}{$\mathrm{R}$} & \multirow[b]{2}{*}{$\begin{array}{c}\mathrm{R} \\
\text { Square }\end{array}$} & \multirow{2}{*}{$\begin{array}{l}\text { Adjusted R } \\
\text { Square }\end{array}$} & \multirow{2}{*}{$\begin{array}{l}\text { Std. Error } \\
\text { of the } \\
\text { Estimate }\end{array}$} & \multicolumn{5}{|c|}{ Change Statistics } & \multirow{2}{*}{$\begin{array}{l}\text { Durbin- } \\
\text { Watson }\end{array}$} \\
\hline & & & & & $\begin{array}{l}\text { R Square } \\
\text { Change }\end{array}$ & \begin{tabular}{|c|}
$\mathrm{F}$ \\
Change
\end{tabular} & df1 & $\mathrm{df2}$ & $\begin{array}{c}\text { Sig. F } \\
\text { Change }\end{array}$ & \\
\hline 1 & $.803^{a}$ & .644 & .636 & 1.31213 & .644 & 79.064 & 3 & 131 & .000 & 1.836 \\
\hline
\end{tabular}

a. Predictors: (Constant), Ukuran, Struktur Modal, Pertumbuhan

b. Dependent Variable: NITAMI

Koefisien korelasi digunakan untuk melihat seberapa erat hubungan dari variasi variabel dependen (Nitami) dijelaskan oleh variasi dari variabel independen (struktur modal, pertumbuhan dan ukuran perusahaan). Berdasarkan hasil perhitungan diperoleh hasil koefisien $\mathrm{R}$ korelasi sebesar 0,803 . Hal ini mengindikasikan bahwa struktur modal, pertumbuhan dan ukuran perusahaan memiliki hubungan yang sangat kuat terhadap Nitami. Mengacu kepada pedoman dalam melakukan interpretasi koefisien korelasi, maka Berdasarkan Tabel diperoleh hasil 0.803 termasuk kedalam korelasi yang sangat kuat. Korelasi yang terjadi adalah teori korelasi positif, yaitu berada diantara $0.80-1.00$ 


\section{Tabel 5. Pedoman Menginterprestasikan Koefisien Korelasi}

\begin{tabular}{|c|c|}
\hline Interval Korelasi & Tingkat Hubungan \\
\hline $0.00-0.199$ & Sangat rendah \\
\hline $0.20-0.399$ & Rendah \\
\hline $0.40-0.599$ & Sedang \\
\hline $0.60-0.799$ & Kuat \\
\hline $0.80-1.000$ & Sangat kuat \\
\hline
\end{tabular}

Sumber: Sugiyono (2001 : 149)

Pengujian hipotesis parsial dilakukan dengan uji t, pengujian ini bertujuan untuk mengetahui pengaruh struktur modal, pertumbuhan dan ukuran perusahaan secara parsial terhadap Nitami. Dengan menggunakan signifikansi $5 \%(\alpha=0,05)$, dan degree of freedom $(\mathrm{n}-\mathrm{k})=135$ diperoleh $\mathrm{t}$-tabel sebesar 1,998

Statistik uji secara parsial struktur modal, pertumbuhan dan ukuran perusahaan terhadap Nitami mengikuti sebaran distribusi $t$ dengan derajat bebas pembilang $v=n-k-1$. Penentuan penerimaan atau penolakan hipotesis pada taraf signifikansi $\alpha$ adalah dengan membandingkan statistik uji dengan nilai $t$-Student tabel. Jika Nilai $t_{\text {hitung }}>t_{\text {tabel }}$ maka hipotesis nol ditolak, artinya terdapat pengaruh struktur modal, pertumbuhan dan ukuran perusahaan terhadap Nitami, sedangkan sebaliknya Jika Nilai $t_{\text {hitung }}<t_{\text {tabel }}$ maka hipotesis nol diterima, artinya tidak terdapat pengaruh struktur modal, pertumbuhan dan ukuran perusahaan terhadap Nitami.

Tabel 6 Pengujian Hipotesis Secara Parsial (Uji t)

\begin{tabular}{|l|c|c|c|}
\hline \multicolumn{1}{|c|}{ Variabel } & t-Stat & t-Tabel & Keterangan \\
\hline Struktur Modal & -5.001 & \multirow{4}{*}{1.998} & H0 ditolak, H1 diterima \\
\cline { 1 - 1 } Pertumbuhan & 6.946 & H0 ditolak, H1 diterima \\
Ukuran Perusahaan & 8.497 & & H0 ditolak, H1 diterima \\
\hline
\end{tabular}

Sumber : Hasil Olah Data

Dengan demikian berdasarkan uji hipotesis individu diatas dengan statistik uji t, maka kita mempunyai tingkat kepercayaan $95 \%(\alpha=5 \%)$ menunjukkan bahwa $t_{\text {hitung }}>t_{\text {tabel }}$ maka hipotesis nol ditolak dan $\mathrm{H}_{1}$ diterima, artinya struktur modal, pertumbuhan dan ukuran perusahaan secara parsial memiliki pengaruh signifikan terhadap Nitami..

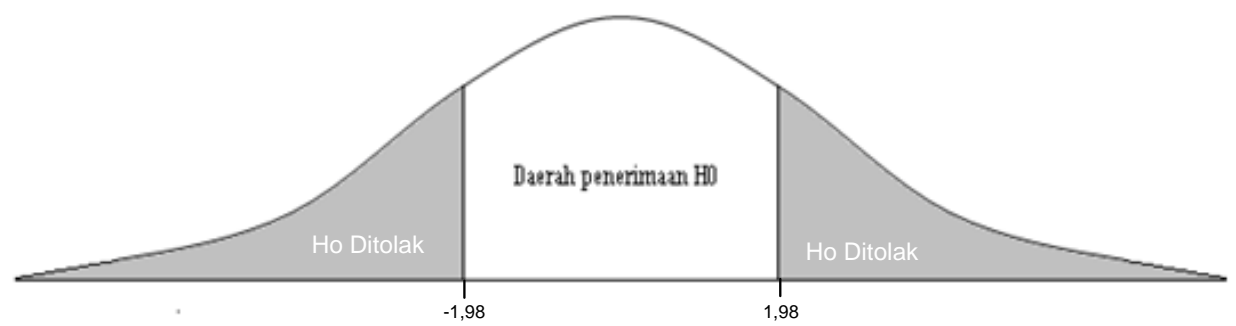

Gambar 4. Daerah Penerimaan dan Penolakan H0 Pengujian Hipotesis Secara Parsial (Uji t) 


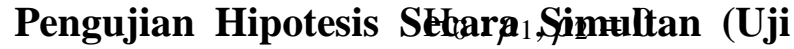
F)

Untuk mengetahui apakah variabel struktur modal, perturhbuhan $\rho$ datno ukuran perusahaan terhadap Nitami mempunyai hubungan/korelasi atau pengaruh yang signifikan atau tidak, maka dilakukan pengujian hipotesis sebagai berikut :
Tidak pengaruh struktur modal, pertumbuhan dan ukuran perusahaan terhadap Nitami.

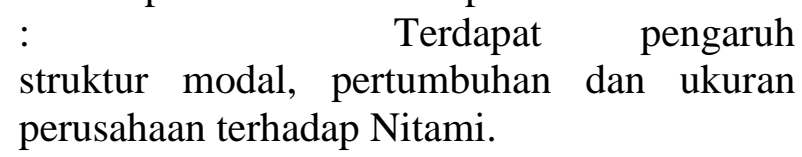

Tabel 7. Uji Hipotesis Simultan

ANOVA $^{a}$

\begin{tabular}{|c|c|c|c|c|c|c|}
\hline & Model & Sum of Squares & $\overline{d f}$ & Mean Square & $\mathrm{F}$ & Sig. \\
\hline \multirow{3}{*}{1} & Regression & 408.371 & 3 & 136.124 & 79.064 & $.000^{\mathrm{b}}$ \\
\hline & Residual & 225.542 & 131 & 1.722 & & \\
\hline & Total & 633.913 & 134 & & & \\
\hline
\end{tabular}

a. Dependent Variable: NITAMI

b. Predictors: (Constant), Ukuran, Struktur Modal, Pertumbuhan

Pengujian hipotesis simultan dilakukan dengan uji F seperti dalam Tabel Pengujian ini bertujuan untuk melihat apakah variabel independen secara bersama-sama mempunyai pengaruh yang signifikan terhadap variabel dependen. Dengan menggunakan signifikansi $5 \%(\alpha=0,05)$ dan degree of freedom (k-1) dan (n-k) maka diperoleh hasil $\mathrm{F}=79.064$.

Kriteria Keputusan :

- Jika $F_{\text {hitung }}>\mathrm{F}_{\text {tabel}}$, maka $\mathrm{H}_{0}$ ditolak

- Jika $F_{\text {hitung }}<\mathrm{F}_{\text {tabel, }}$, maka $\mathrm{H}_{\mathrm{a}}$ diterima

Dimana diketahui $\mathrm{F}_{\text {tabel }}=\mathrm{F}_{(0,05: 3: 135)}=2.68$;

$F_{\text {hitung }}>F_{\text {tabel }} 79.064>2,68$

Hal ini berarti $\mathrm{H}_{0}$ ditolak dan $\mathrm{H}_{1}$ diterima, maka berdasarkan uji hipotesis di atas dapat dinyatakan keabsahan (signifikan) atas hipotesis yang dikemukakan oleh peneliti yaitu : " Terdapat pengaruh yang signifikan antara struktur modal, pertumbuhan perusahaan dan ukuran perusahaan terhadap Nilai tambah ekonomi”.

Hal ini berarti bahwa secara bersamasama variasi variabel-variabel independen (struktur modal, pertumbuhan dan ukuran perusahaan) mempunyai pengaruh yang signifikan terhadap variasi variabel dependen Nitami. Dengan demikian Hipotesis secara simultan yang menyatakan "Diduga bahwa variabel-variabel independen struktur modal, pertumbuhan dan ukuran perusahaan secara bersama-sama mempunyai pengaruh signifikan terhadap Nitami "diterima".

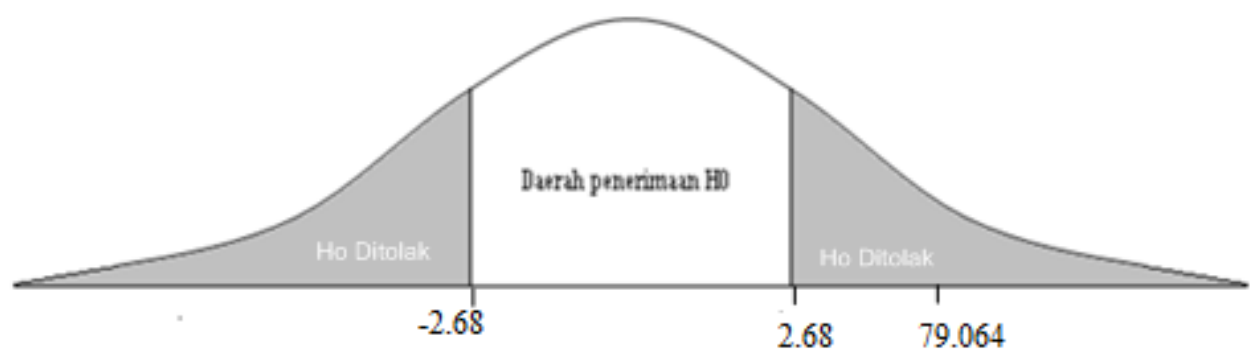

25 | Jurnal Aset (Akuntansi Riset) Vol.7 | No.1 | 2015 


\section{Gambar 5. Daerah Penerimaan dan Penolakan Ho Pengujian Hipotesis Secara Simultan (Uji F)}

\section{Koefisien Determinasi}

Untuk mengetahui seberapa besar kontribusi variabel independen yaitu struktur modal, pertumbuhan dan ukuran perusahaan mempengaruhi variabel dependen yaitu Nilai
Tambah Ekonomi. maka kita menggunakan analisis koefisien determinasi yaitu kuadrat nilai korelasi dikalikan $100 \%$

Tabel 8. Hasil Perhitungan Pengaruh

Model Summary

\begin{tabular}{|c|r|r|r|r|r|r|r|r|r|r|}
\hline \multirow{2}{*}{ Model } & \multirow{2}{*}{$\mathrm{R}$} & \multirow{2}{*}{$\begin{array}{c}\mathrm{R} \\
\text { Square }\end{array}$} & \multirow{2}{*}{$\begin{array}{c}\text { Adjusted } \mathrm{R} \\
\text { Square }\end{array}$} & $\begin{array}{c}\text { Std. Error } \\
\text { of the } \\
\text { Estimate }\end{array}$ & $\begin{array}{l}\text { R Square } \\
\text { Change }\end{array}$ & $\begin{array}{c}\mathrm{F} \\
\text { Change }\end{array}$ & $\mathrm{df1}$ & $\mathrm{df2}$ & $\begin{array}{c}\text { Sig. F } \\
\text { Change }\end{array}$ & \multirow{2}{*}{$\begin{array}{c}\text { Durbin- } \\
\text { Watson }\end{array}$} \\
\hline 1 & $.803^{\mathrm{a}}$ & .644 & .636 & 1.31213 & .644 & 79.064 & 3 & 131 & .000 & 1.836 \\
\hline
\end{tabular}

a. Predictors: (Constant), Ukuran, Struktur Modal, Pertumbuhan

b. Dependent Variable: NITAMI

$\mathrm{Kd}=\mathrm{R}^{2} \times 100 \%$

$\mathrm{Kd}=(0.803)^{2} \mathrm{X} 100 \%=64,4 \%$

Dari analisis di atas dapat dilihat bahwa kontribusi pengaruh struktur modal, pertumbuhan dan ukuran perusahaan terhadap variabel Nitami sebesar $64,4 \%$ dan sisanya sebesar $35.6 \%$ merupakan kontribusi dari faktor-faktor lainnya yang tidak diteliti.
Untuk menguji pengaruh secara parsial variabel struktur modal, pertumbuhan dan ukuran perusahaan terhadap Nitami maka harus menggunakan rumus rumus uji individu : Koefisien Beta $x$ Zerro order (correlation) yang bisa dilihat pada tabel Coefisients

\section{Tabel 9 Hasil Uji Individu}

\begin{tabular}{|c|c|c|c|}
\hline Variabel & Beta & Zero Order & Uji Individu \\
\hline Struktur Modal & -0.271 & -0.454 & $12.3 \%$ \\
\hline Pertumbuhan & 0.381 & 0.568 & $21.6 \%$ \\
\hline Ukuran & 0.472 & 0.646 & $30.5 \%$ \\
\hline \multicolumn{3}{|c|}{ Total } & $64.4 \%$ \\
\hline
\end{tabular}

Sumber : data diolah 2014

Dari hasil uji pengaruh secara individu diatas dapat diketahui bahwa variabel ukuran perusahan memberikan pengaruh yang cukup besar, yakni sebesar $30.5 \%$ dibandingkan dengan variabel-variabel lainnya terhadap Nitami. Sedangkan berdasarkan table 9, Pertumbuhan berpengaruh sebesar $21.6 \%$, dan Struktur modal berpengaruh sebesar $12.3 \%$, terhadap Nitami.

\section{Pembahasan Analisis Verifikatif untuk menjelaskan signifikan}

Berdasarkan hasil analisis diatas maka dilakukan pembahasan mengenai pengaruh Struktur Modal, Tingkat Pertumbuhan Perusahaan dan Ukuran Perusahaan terhadap EVA/Nitami. Tingkat ukuran perusahaan memberikan pengaruh yang sangat besar terhadap EVA/Nitami, sehingga semakin meningkat ukuran perusahaan maka perolehan Nitami juga akan meningkat. Ukuran perusahaan mempunyai pengaruh sebesar $30.5 \%$ terhadap EVA/ Nitami. berdasarkan 
hasil uji hipotesis diperoleh hasil yang signifikan pula. Hal ini sejalan dengan dengan teori dan hasil penelitian sebelumnya yang menyatakan bahwa sangat erat kaitan antara Nitami dengan tingkat ukuran perusahaan, yang menyatakan bahwa Nitami digunakan sebagai penilai kinerja perusahaan dimana fokus penilaian kinerja adalah pada penciptaaan nilai (value creation) dan Tobin's $q$ adalah indikator untuk mengukur kinerja perusahaan, khususnya tentang nilai perusahaan, yang menunjukkan suatu proforma manajemen dalam mengelola aktiva perusahaan. (Tendelilin, 2001).

Ukuran Perusahaan merupakan factor yang mempengaruhi Nilai Tambah Ekonomi dengan koefisien jalur sebesar 0.534 artinya jika Ukuran Perusahaan ditingkatkan maka akan menyebabkan peningkatan perolehan Nitami dengan pengaruh sebesar $21.6 \%$. Berdasarkan hasil uji hipotesis diperoleh bahwa Ukuran Perusahaan berpengaruh secara signifikan terhadap EVA/Nitami. Hal ini sesuai dengan teori yang dikemukakan oleh Agung Sartono (2001, 103), yang menyatakan bahwa nilai total asset yang meningkat akan mempengaruhi NOPAT sedangkan NOPAT merupakan dasar perhitungan Nitami.

Struktur Modal mempunyai pengaruh yang negative terhadap EVA/ Nitami, artinya jika struktur modal ditingkatkan maka akan menyebabkan penurunan perolehan Nitami sebesar $-0,010$ dengan pengaruh sebesar $12.3 \%$. Berdasarkan hasil uji hipotesis diperoleh bahwa Struktur Modal berpengaruh secara signifikan terhadap EVA/ Nitami.

Hal ini sesuai dengan teori yang dikemukakan oleh Siddharta (1997:176-177), Penentuan strategi struktur modal oleh top management perusahaan sangat mempengaruhi keberhasilan perusahaan dalam mencetak profit yang selanjutnya mengarah kepada penciptaan Nitamis. Struktur modal yang ideal adalah yang memberikan biaya modal minimum dengan pencapaian Nitami maksimum. Penggunaan struktur modal yang besar dapat membuat biaya modal semakin besar.

Sedangkan pengujian bersama-sama berdasarkan analisis hasil uji hipotesis diketahui bahwa Struktur Modal $\left(\mathrm{X}_{1}\right)$, tingkat pertumbuhan perusahaan $\left(\mathrm{X}_{2}\right)$ dan ukuran perusahaan $\left(\mathrm{X}_{3}\right)$ secara bersama-sama berpengaruh terhadap Nitami/ Nitami (Y), dengan pengaruh sebesar 0,644 dan sisanya sebesar 0.356 diprediksi dari variable diluar model yang tidak diindetifikasikan dalam penelitian ini.

Hal ini sesuai dengan teori-teori dan penelitian terdahulu mengenai hubungan Struktur Modal, Tingkat Pertumbuhan Perusahaan dan Ukuran Perusahaan terhadap Nitami yang dikemukakan oleh (Tendellin, 2001) bahwa Nitami digunakan sebagai penilai kinerja perusahaan dimana fokus penilaian kinerja adalah pada penciptaaan nilai (value creation) dan tingkat pertumbuhan Tobin's $q$ adalah indikator untuk mengukur kinerja perusahaan, juga pendapat dari Siddharta (1997:176-177), Penentuan strategi struktur modal oleh top management perusahaan sangat mempengaruhi keberhasilan perusahaan dalam mencetak profit yang selanjutnya mengarah kepada penciptaan Nitamis, serta pendapat dari Agung Sartono (2001, 103), yang menyatakan bahwa nilai total asset yang meningkat akan mempengaruhi NOPAT sedangkan NOPAT merupakan dasar perhitungan Nitami.

\section{SIMPULAN}

Rata-rata perolehan nilai tambah ekonomi periode tahun 2009-2013 sebesar Rp. $817.480,10$ hal ini menunjukkan secara ratarata perusahaan yang masuk dalam komponen Indeks 30 memperoleh nilai tambah yang positif artinya rata-rata perusahaan berhasil menciptakan nilai (create value) bagi pemilik modal sehingga menandakan bahwa kinerja keuangannya telah baik, perusahaan dengan rata-rata perolehan Economic Value Added / Nitami terbesar adalah PT. Bank BRI dengan nilai $R p .7,228,981$ dan perusahaan yang ratarata EVA nya negative terbesar adalah PT. Bank Mandiri sebesar Rp. -2,702,804, artinya secara rata-rata PT. Bank Mandiri selama kurun waktu 5 tahun tidak mengalami proses nilai tambah ekonomis bagi perusahaan dalam melakukan kegiatan operasionalnya, hal ini menunjukkan PT. Bank Mandiri belum sejalan 
dengan tujuan perusahaan, yaitu memaksimumkan nilai perusahaan.

Pengaruh Struktur Modal terhadap Nilai Tambah Ekonomi sebesar 12,3\%, pengaruh Tingkat pertumbuhan perusahaan terhadap Nilai Tambah Ekonomi sebesar 21,6\%, pengaruh Ukuran Perusahaan terhadap Nilai Tambah Ekonomi sebesar 30,5\%, dan pengaruh Struktur Modal, Tingkat Pertumbuhan Perusahaan dan Ukuran Perusahaan secara bersama-sama/ simultan terhadap terhadap Nilai Tambah Ekonomi sebesar $64,4 \%$.

Hasil pengujian Hipotesis-1 mengenai pengaruh Struktur Modal, Tingkat pertumbuhan perusahaan dan Ukuran Perusahaan terhadap Nilai Tambah Ekonomi berpengaruh secara parsial dan signifikan terhadap Nilai Tambah Ekonomi dan Hasil pengujian Hipotesis-2 mengenai pengaruh Struktur Modal, Tingkat Pertumbuhan Perusahaan dan Ukuran Perusahaan secara bersama-sama/ simultan terbukti berpengaruh secara signifikan terhadap Nilai Tambah Ekonomi.

\section{DAFTAR PUSTAKA}

Daniati, Ninna dan Suhairi, 2006, Pengaruh Kandungan Informasi Komponen Laporan Arus Kas, Laba Kotor, Dan Size Perusahaan Terhadap Expected Return Saham(Survey Pada Industri Textile Dan Automotive Yang Terdaftar Di BEJ, SNA Padang.

Deden Sutisna, Research Methods and Techniques Preparation of the Thesis, Bandung, 2012

Eugene Brigham dan Joel F. Houston, Manajemen Keuangan, Buku 1, edisi 8, PT. Erlangga, Jakarta,2000)

Erich A, Helfert. 2000. Teknik Analisa Keuangan; Edisi 8, Cetakan Pertama, Penerbit Erlangga, Jakarta.

Horngren, T, Charles, 1998. Akuntansi di Indonesia. Jakarta: Salemba Empat.

Knight, James A., 1998. Value Based Management, Developing a Systematic
Approach to Creating Shareholder Value, Mc Graw-Hil

Kallapur Sanjay and A. Mark Trombley, 1999, The Association between Investment Opportuniy Set Proxiest and Realized Growth, Journal Finance and Bussines. Inda School of Bisnis, India.

Kallapur Sanjay and A. Mark Trombley, 2001, The Investment Opportunity Set, Determined, Concequences and Measurement, Managerial Finance, India. Lisa Linawati Utomo, 1999 "Nilai tambah ekonomi sebagai Ukuran Keberhasilan Kinerja Keuangan Manajemen Perusahaan" , Jurnal akuntansi dan Keuangan, Vol.1 No 1, Hal 28-42.

Machfoedz, Mas'ud, 1994, Financial Ratio Analysis and The Prediction of Earnings, Changes in Indonesia, Kelola, Volume 3 no. 7, hal 114 137

Mulyadi. 2001. Akuntansi Manajemen. Yogyakarta: UPP STIE - YKPN.

Stewart III, G. Bennet, \& Joel M. Stern, 1995. EVA Works - But Not if You Make These Common Mistakes, Fortune, May 1, 117118

Teuku Mirza dan Imbuh S, 1999, “Konsep Nilai tambah ekonomi": Pendekatan

Untuk Menentukan Nilai Riil Manajemen", Usahawan, No.01, Th. XXVIII, Januari.

Thakor, Anjan V, 2000. Becoming A Better value Creator, How to Improce the Company's Bottom Line and Your Own, Jossey-Bass, A Wiley Company.

Weston, J. Fred dan Thomas E. Copeland. 1996. Manajemen Keuangan. Jakarta: Erlangga. 